\title{
Peningkatan Kualitas Pembelajaran TPA Al-Hikmah melalui Pelatihan Penggunaan Perangkat Audio Visual
}

\author{
*Mochammad Taufik"1, Hudiono², Aad Hariyadi ${ }^{3}$, Ridho Hendra Yoga Perdana ${ }^{4}$, \\ Amalia Eka Rakhmania ${ }^{5}$ \\ 1, 2, 3, 4, 5 Politeknik Negeri Malang, Malang, Indonesia
}

\begin{tabular}{|c|c|}
\hline (A) Check for updates open Oaccess @C) & DOI: https://doi.org/10.53621/jippmas.v1i2.53 \\
\hline Informasi Artikel & ABSTRAK \\
\hline tikel: & \multirow{11}{*}{$\begin{array}{l}\text { Taman Pendidikan Al-Qur'an adalah lembaga pendidikan yang } \\
\text { memberikan pendidikan dan pengajaran secara klasikal yang bertujuan } \\
\text { untuk memberi tambahan pengetahuan agama Islam kepada pelajar- } \\
\text { pelajar yang merasa kurang menerima pelajaran agama Islam di sekolah. } \\
\text { Taman Pendidikan Al-Qur'an Al Hikmah di kelurahan Buring, } \\
\text { kecamatan Kedungkandang, kota Malang yang sudah lama berdiri sejak } \\
\text { tahun } 2014 \text {, tetapi sarana dan prasarana terkait proses pembelajaran yang } \\
\text { dimilikinya sangat terbatas sehingga Pengajar di dalam memberikan } \\
\text { materi belajar siswa masih menggunakan metode tradisional } \\
\text { menggunakan papan tulis. Penggunaan sarana multimedia dapat } \\
\text { menjadi pendukung untuk menerapkan sistem pembelajaran baru tanpa } \\
\text { harus meninggalkan sistem tradisional. Adanya pelatihan diharapkan } \\
\text { dapat meningkatkan kemampuan pengajar untuk menggunakan } \\
\text { perangkat audio visual sehingga dapat memperbaiki kualitas } \\
\text { pembelajaran menjadi lebih modern dan mengikuti perkembangan } \\
\text { teknologi tanpa meninggalkan esensi pembelajaran. Hasil menunjukkan } \\
\text { bahwa penggunaan perangkat audio visual di dalam pembelajaran TPA } \\
\text { Al-Hikmah meningkatkan ketertarikan santri dan mempermudah proses } \\
\text { belajar mengajar. }\end{array}$} \\
\hline Diterima: 28 September 2021 & \\
\hline Revisi Akhir: 03 November 2021 & \\
\hline Disetujui: 09 November 2021 & \\
\hline Terbit: 31 Desember 2021 & \\
\hline Kata & \\
\hline Kualitas Pembelajaran & \\
\hline Pelatihan & \\
\hline Perangkat Audio Visual & \\
\hline Taman Pendidikan A & \\
\hline & \\
\hline
\end{tabular}

\section{PENDAHULUAN}

Pendidikan keagamaan bagi anak usia dini memberikan pengaruh pada pembentukan pribadi, mental dan akhlaknya. Oleh karena itu pendidikan keagamaan melalui TPA (Taman Pendidikan Al-Qur'an) perlu terus digalakkan, dioptimalkan dan dilaksanakan secara bersama-sama oleh masyarakat dan pemerintah. TPA merupakan salah satu bentuk jalur pendidikan agama yang diorientasikan untuk meningkatkan taraf pengetahuan terhadap Islam khususnya keagamaan baca tulis dan pengamalan AlQur'an dan kemampuan membaca Al-Quran yang pada umumnya memiliki peserta didik dari usia 7-12 tahun atau usia masuk Sekolah Dasar (Setiawan et al., 2018; Sri Bulan, \& W Eka Wahyudi, 2021). Kebanyakan pembelajaran di TPA masih tradisional (Indra, 2020). Guru menjelaskan materi pelajaran dengan menggunakan papan tulis atau dengan peragaan gambar. Banyak guru belum menggunakan media pembelajaran berbasis komputer dengan alasan guru yang mengajar belum mengusai media pembelajaran berbasis computer (L. D. Putra \& Suyitno, 2018). Beberapa hal penting yang harus dipersiapkan guru meliputi peningkatan motivasi, kapasitas pengetahuan, dan keterampilan. Sejauh ini keterbatasan pengetahuan dan keterampilan serta lemahnya motivasi guru berakibat kepada stagnannya kualitas institusi pendidikan yang berujung pada lemahnya kualitas output siswa (Hariani \& Andayani, 2020).

Terdapat beberapa faktor yang mempengaruhi kecepatan pemahaman terhadap sebuah materi belajar yaitu tingkat kecerdasan, motivasi siswa, metode pengajaran, dan fasilitas pembelajaran (Aminudin, Basuki, et al., 2019). Dalam hal ini, yang dapat ditunjang adalah motivasi, metode, dan fasilitas. Motivasi dapat dinaikkan dengan 
adanya metode pengajaran dan fasilitas yang memadai. Metode pembelajaran sebaiknya beralih dari cara tradisional menjadi mengikuti perkembangan teknologi, misalnya melalui penggunaan aplikasi, video interaktif, dan sebagainya. Beberapa penelitian telah mengembangkan media pembelajaran utuk TPA, seperti perangkat multimedia interaktif untuk metode tilawati (Aminudin, Basuki, et al., 2019), (Aminudin, Sari, et al., 2019) maupun qiro'ati (L. D. Putra \& Suyitno, 2018), pengenalan huruf hijaiyah (Saputra \& Yuniansyah, 2018) (L. D. Putra \& Suyitno, 2018), tajwid (Hidayat et al., 2021), dan media pembelajaran Al-Qur'an berbasis android (Fathoni et al., 2018).

Tidak hanya ketersediaan aplikasi multimedia, tetapi keterampilan penggunaan perangkat teknologi informasi (Hariani \& Andayani, 2020) pendukung pembelajaran, utamanya perangkat multimedia seperti LCD proyektor, laptop dengan software power point, video, dan perlengkapan sound system sangat diperlukan untuk menunjang proses pembelajaran, baik untuk meningkatkan minat siswa maupun peningkatan kualitas pembelajaran. Selain keterampilan pengajar yang termasuk faktor internal pendukung/penghambat pelaksanaan pembelajaran, faktor eksternal berupa ketersediaan fasilitas, sarana prasarana, dan media pembelajaran di TPA juga perlu diperhatikan (Setiawan et al., 2018).

Pada umumnya proses pembelajaran di TPA terutama yang berada di daerah pelosok sangat membutuhkan atau kekurangan sarana pembelajaran yang memadai. Sementara di sisi lain pemerintah dalam hal ini dinas pendidikan tidak berdaya dengan banyaknya pengajuan penambahan maupun perbaikan sarana pembelajaran yang ada mengingat terbatasnya anggaran yang tersedia (Saefulloh, 2015). Dengan kenyataan sarana pembelajaran yang ada sekarang di banyak pendidikan jenis TPA ini akhirnya menemui kegagalan ditandai dengan berkurangnya jumlah siswa secara terus menerus sampai akhirnya pendidikan TPA tidak memiliki siswa karena tidak mampu mengatasi kendala sarana pembelajaran tersebut. Maka dari itu, perlu adanya bantuan fasilitas multimedia penunjang pembelajaran sekaligus pelatihan penggunaan fasilitas tersebut kepada pengajar TPA untuk meningkatkan kualitas PBM di TPA.

\section{PERMASALAHAN}

Dari data potensi kegiatan Keagamaan Masyarakat di kelurahan Buring, kecamatan Kedungkandang dalam kaitannya dengan pelaksanaan pendidikan TPA, terbukti dengan jumlah siswa yang sudah mencapai 40 siswa ini, dengan tidak diimbangi dengan pemakaian sarana dan prasarana yang memadai maka akan timbul permasalahan tersendiri, antara lain:

1. Proses Belajar mengajar siswa menjadi monoton dan cepat jenuh

2. Siswa menjadi kurang tertarik jika proses belajar dan mengajarnya tidak oprtimal

Dari beberapa permasalahan di atas, aparat kelurahan Buring mengharapkan adanya sentuhan teknologi di dalam proses pembelajaran di pendidikan TPA yang dimilikinya, sehingga proses belajar mengajar menjadi lebih dinamis. Setelah dilakukan diskusi antara pengusul dengan mitra, maka prioritas permasalahan yang akan dipecahkan solusinya adalah;

1. Perlu adanya peningkatan di dalam proses pembelajaran dengan menambahkan proyektor sebagai sarana untuk paparan teori dan yang berkaitan dengan tampilan video. 
2. Dibutuhkan 1 set audio lengkap untuk lebih meningkatkan proses pembelajaran dalam kaitannya dengan suara, misalnya; film-film kisah kenabian, mendengarkan contoh-contoh suara merdu pembacaan alquran dan lain-lain

\section{METODE PELAKSANAAN}

Kegiatan PkM ini dilaksanakan pada bulan April - Juni 2021 di TPA Al-Hikmah kelurahan Buring, kecamatan Kedungkandang, kota Malang. Pada bulan April dilakukan survey lokasi dan kebutuhan mitra. Pada bulan Juni, dilakukan pemberian alat dan pelatihan penggunaan media pembelajaran. Metode yang digunakan untuk kegiatan PkM ini terlihat pada Gambar 1.

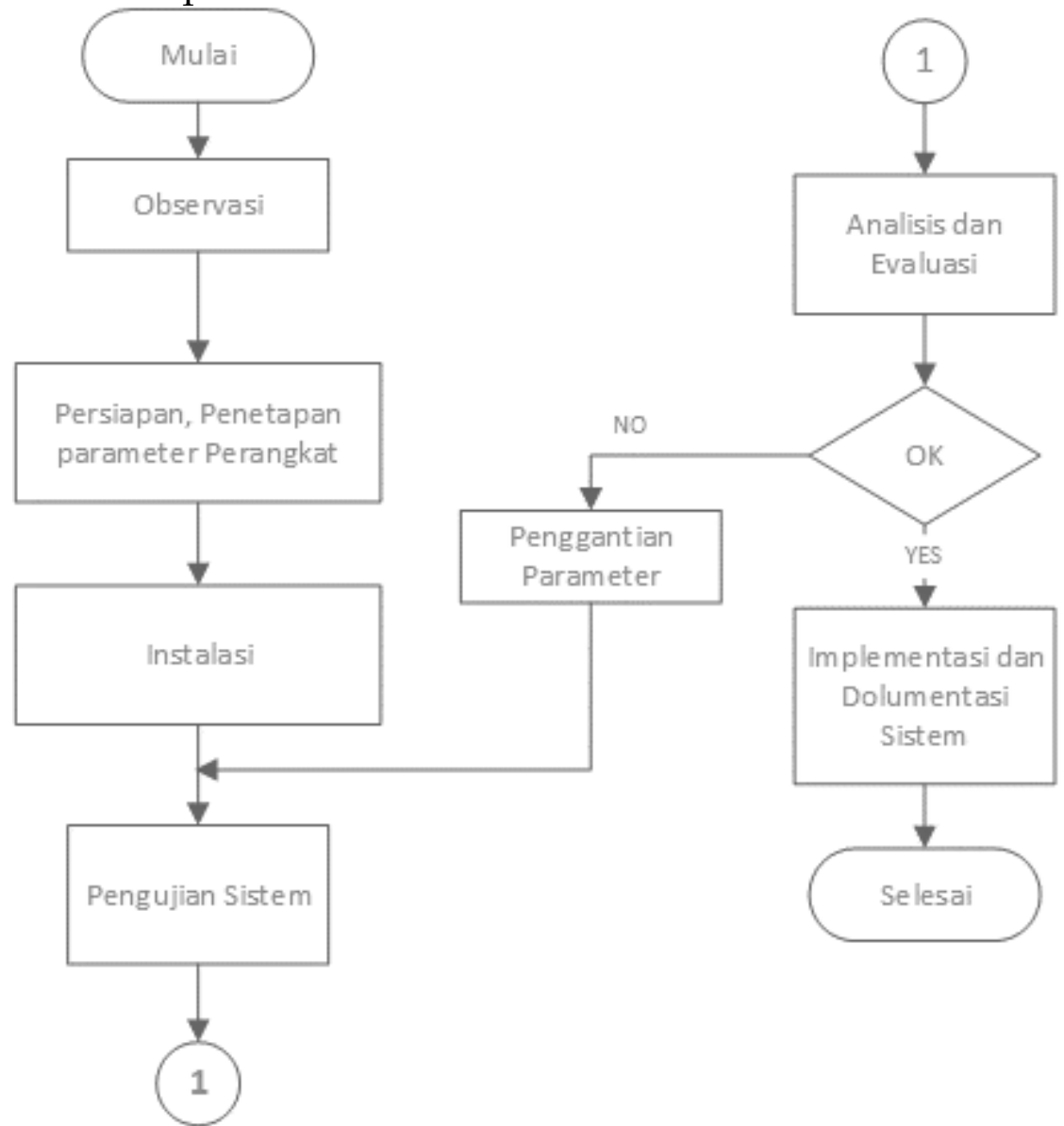

Gambar 1. Rencana Pelaksanaan PkM

1. Observasi di lapangan untuk mempermudah pelaksanaan pemilihan parameter spesifikasi perangkat yang akan digunakan, dan instalasi

2. Kajian dan analisa data lokasi dan ruang dan selanjutnya digunakan dasar untuk penetapan perangkat yang digunakan.

3. Instalasi perangkat audio visual untuk proses pembelajaran siswa TPA .

4. Melakukan pengujian kemampuan perangkat audio visual untuk proses pembelajaran

5. Pemberian tutorial penggunaan audio visual untuk pembelajaran

6. Analisis dan Evaluasi kegiatan. Apabila perangkat kurang baik settingnya, maka akan diperbaiki di tahap ini.

7. Implementasi, Dokumentasi, dan Pelaporan 
Sasaran dari kegiatan pengabdian kepada masyarakat ini adalah pengajar maupun staf TPA Al-Hikmah. Peserta pelatihan meliputi 8 orang staf dan pengajar.

\section{PELAKSANAAN}

Pada kegiatan kali ini, dilakukan survey terlebih dahulu mengenai permasalahan kebutuhan mitra untuk meningkatkan proses belajar mengajar di TPA. Lokasi TPA AlHikmah terletak di Mushola Al-Hikmah, JL. KH. Malik Dalam, Kecamatan Buring, Kota Malang. Jarak TPA dengan kampus Politeknik Negeri Malang adalah 10.2 km, yang dapat ditempuh dalam waktu 30 menit berkendara seperti terlihat pada Gambar 2.

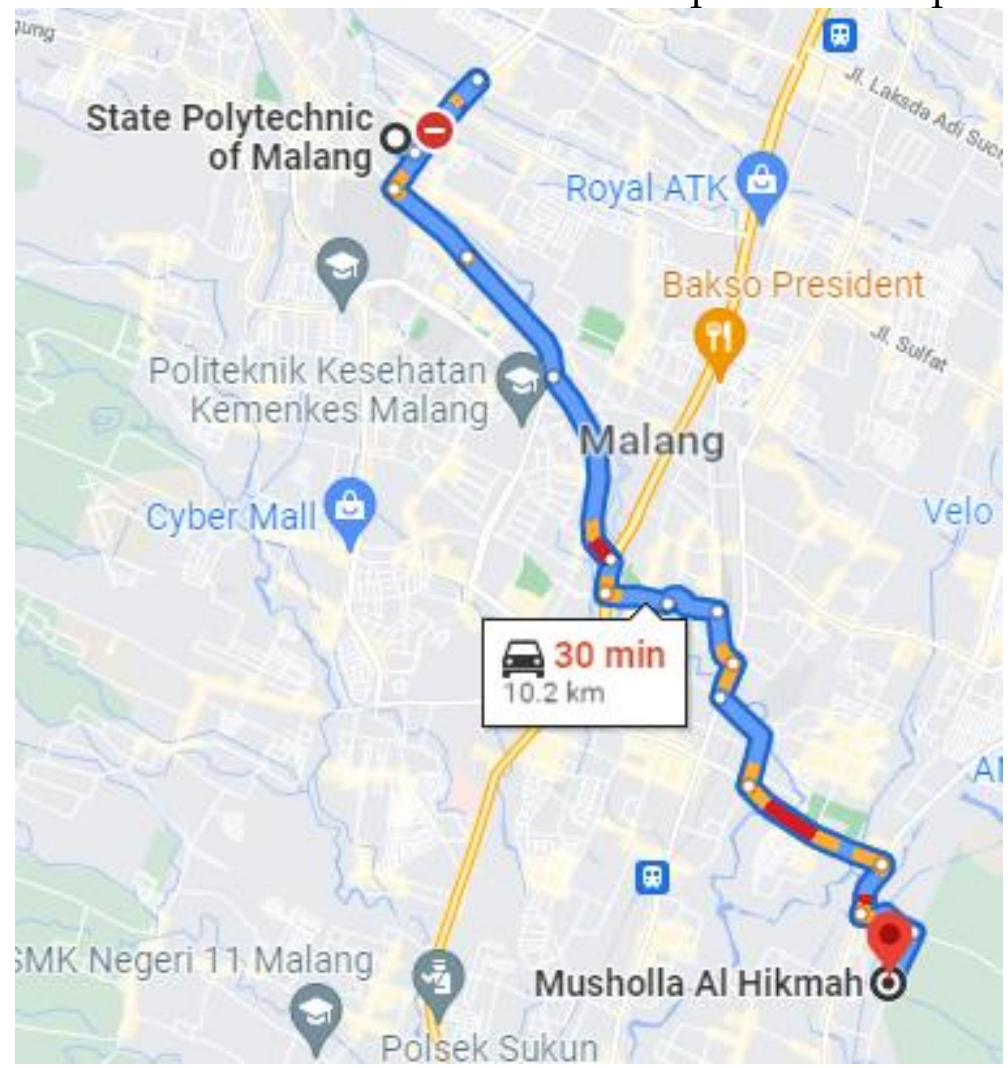

Gambar 2. Lokasi TPA Al Hikmah dari kampus Politeknik Negeri Malang

Setelah permasalahan terpetakan dan tim pengabdian menawarkan solusi yang dapat diterima mitra, langkah selanjutnya adalah tahap pemberian perangkat media pembelajaran. Pada tahap ini, diberikan layar proyektor, proyektor LCD, dan perangkat audio portable untuk mendukung proses PBM di TPA. Pelatihan penggunaan dan perawatan alat dilakukan bersamaan dengan pemberian alat. Peserta pelatihan adalah 8 orang staf dan pengajar TPA Al-Hikmah. Langkah terakhir adalah evaluasi kegiatan. 


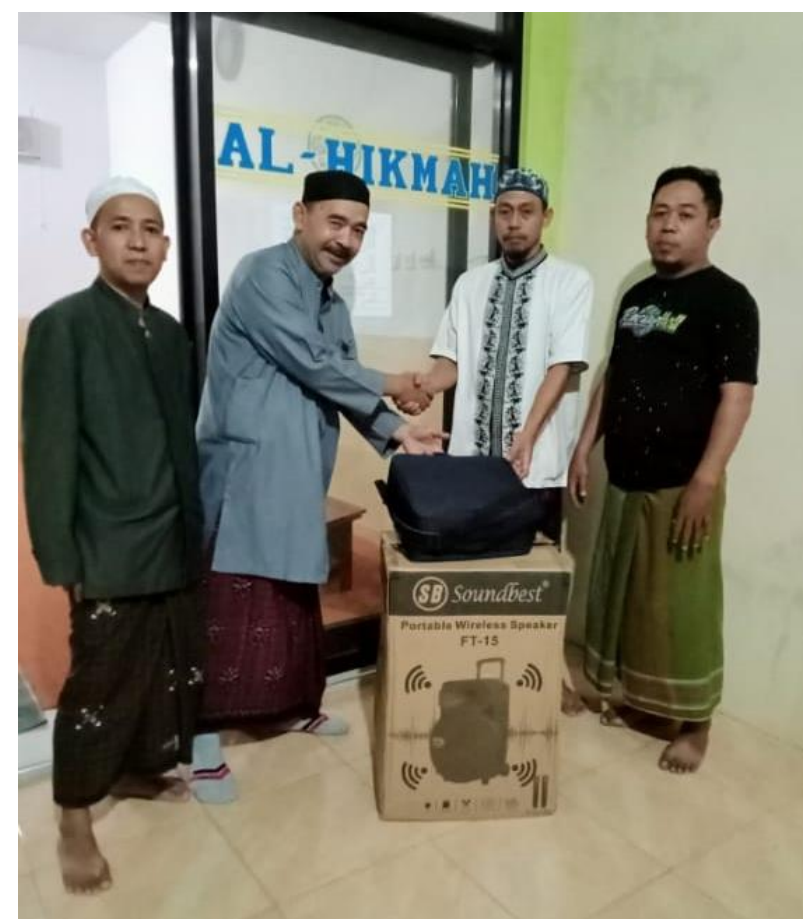

(a)

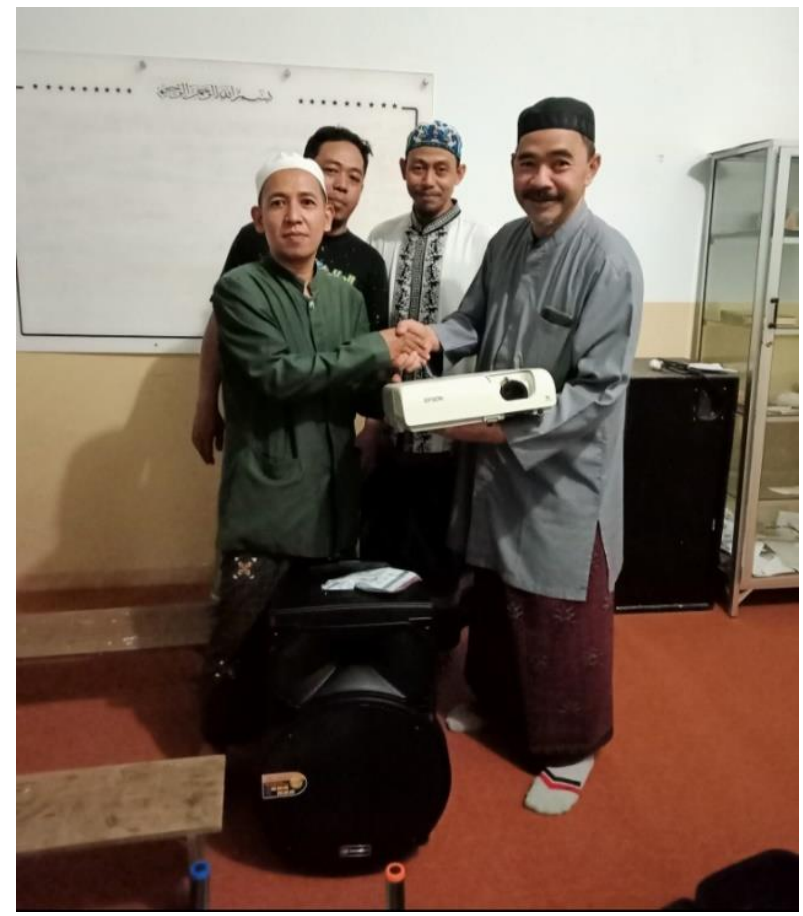

(b)

Gambar 3. Penyerahan fasilitas pembelajaran (a) sound system (b) LCD proyektor

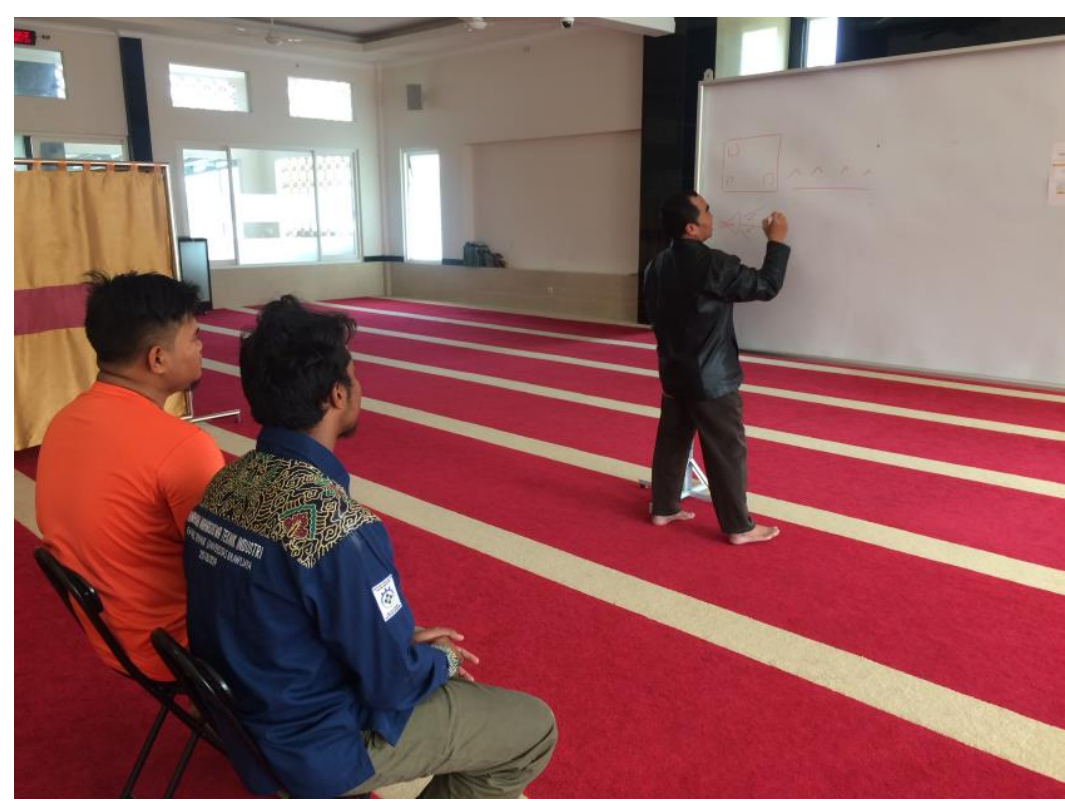

Gambar 4. Pelatihan penggunaan perangkat multimedia

\section{HASIL DAN DISKUSI}

Selama pelatihan, peserta diberi informasi mengenai prinsip kerja alat, fungsi tomboltombol, dan cara penggunaan saat proses pembelajaran. Alat pertama yang diajarkan adalah LCD proyektor. Pertama, fungsi masing-masing tombol pada LCD dan remote control-nya dijelaskan. Kemudian, proyektor disambungkan ke laptop. Cara penyambungan menggunakan jenis konektor yang berbeda, VGA dan HDMI juga diinformasikan. Pada tahap ini, proses menampilkan presentasi power point, dokumen pdf/word, maupun file video, baik yang berupa file mp4 maupun streaming dari internet 
diajarkan pada para pengajar. Setelah tim PkM melakukan demonstrasi, peserta mencoba mulai dari proses penyambungan dan melakukan tanya jawab. Alat kedua, perangkat audio portable didemonstrasikan dengan tahapan yang sama.

LCD proyektor diberikan untuk membantu menampilkan materi yang diajarkan kepada siswa. Sebelumnya, pengajaran di TPA Al-Hikmah masih menggunakan papan tulis. Hal ini sedikit menyulitkan siswa yang berada di belakang kelas karena tulisan kurang jelas terbaca. Waktu pun kurang efisien karena pengajar harus menuliskan materi di papan, menghapusnya jika salah atau mengganti dengan materi baru. Dengan adanya LCD proyektor, diharapkan materi yang ditampilkan dapat dengan jelas terlihat dari belakang kelas. Waktu pembelajaran juga dapat digunakan dengan efisien karena pengajar tidak perlu lagi menulis ulang materi di papan tulis.

Sedangkan perangkat audio portable utamanya dapat mendukung proses pembelajaran yang membutuhkan tampilan suara/video, misalnya pengucapan huruf hijaiyah dapat dilakukan dengan memutar video. Suara akan dapat didengar dengan jelas bahkan dari belakang ruangan. Video yang menunjukkan gerakan mulut saat melafalkan huruf hijaiyah juga dapat ditunjukkan melalui LCD proyektor.

Selama penyampaian materi, peserta menunjukkan antusiasme dalam mengikuti pelatihan, terbukti saat sesi tanya jawab, terdapat beberapa pertanyaan dari peserta. Di akhir sesi, ketika pemateri memberikan feedback dengan secara acak menanyai peserta tentang materi yang diberikan, mereka dapat menjawab dengan baik.

Evaluasi kegiatan dilakukan dengan membagikan kuesioner kepuasan peserta terhadap pelatihan yang diberikan. Terdapat 4 pertanyaan yang diberikan, meliputi kepuasan mitra dengan penyampaian materi oleh tim PkM, kepuasan mitra mengenai pelaksanaan kegiatan PkM, kebermanfaatan kegiatan yang dilakukan, serta keberlanjutan program.

Terlepas dengan keterbatasan pada masa pandemic Covid-19, hasil menunjukkan bahwa 75\% peserta menyatakan puas dengan materi dan metode penyampaian tim PkM, sedangkan $25 \%$ sisanya menyatakan sangat puas. $63 \%$ peserta menyatakan sangat puas dengan kegiatan PkM yang dilakukan, sedangkan 37\% menyatakan puas. 88\% peserta menyatakan kegiatan PkM sangat bermanfaat bagi mereka, sedangkan 13\% menyatakan bermanfaat. Keberlanjutan kegiatan PkM sangat disetujui oleh 63\% peserta, sedangkan $37 \%$ sisanya menyatakan setuju.

Fasilitas sarana prasarana pengajaran semakin meningkat dengan bantuan perangkat audio visual yang diberikan oleh tim, begitupula kemampuan pengajar dalam mengoperasikan perangkat, menjadi lebih mahir setelah pelatihan yang diberikan. Bantuan sarana prasarana maupun pelatihan untuk peningkatan kemampuan pengajar sangat diperlukan oleh lembaga pendidikan, baik sekolah maupun TPA. Beberapa kegiatan PkM serupa, misalnya pengembangan prasarana (H. W. S. Putra et al., 2021), pengembangan dan implementasi software multimedia (Adhy Sugara et al., 2020; Aminudin, Sari, et al., 2019; L. D. Putra \& Suyitno, 2018; Saputra \& Yuniansyah, 2018), maupun peningkatan kemampuan pengajar TPA (Al-achmad et al., 2019; Hariani \& Andayani, 2020) memberikan dampak positif bagi peningkatan kualitas proses belajar mengajar di TPA. 


\section{KESIMPULAN}

Dari kegiatan PkM ini, dapat disimpulkan bahwa staf dan pengajar TPA Al-Hikmah mendapat peningkatan wawasan dan keterampilan dalam penggunaan media audio visual seperti LCD proyektor dan audio portable. Ke depannya, sesuai dengan saran dari mitra, kegiatan PkM ini dapat dikembangkan dengan adanya pelatihan pembuatan media pembelajaran untuk memaksimalkan fasilitas yang diberikan.

\section{UCAPAN TERIMA KASIH}

Penulis menyampaikan terima kasih kepada Politeknik Negeri Malang yang telah mendanai kegiatan PkM ini.

\section{DAFTAR PUSTAKA}

Adhy Sugara, E., Barovih, G., \& Nurussama, N. (2020). The Impact of Daily Prayers Multimedia Application towards Student's Learning Interest. Proceedings of the Proceedings of the 5th International Conference on Education in Muslim Society, ICEMS 2019,30 September - 01 October 2019, Jakarta, Indonesia. https:/ / doi.org/10.4108/eai.30-9-2019.2291168

Al-achmad, M. I., Wahidin, U., \& Priyatna, M. (2019). Upaya Guru Taman Pendidikan Al-Qur'an dalam Pembelajaran Al-Qur' an di Rukun Warga (Rw) 8 Desa Pasir Eurih Kecamatan Tamansari Kabupaten Bogor Tahun 2019. Prosiding Al Hidayah Pendidikan Agama Islam, 65-78.

Aminudin, A., Sari, Z., \& Basuki, S. (2019). Aplikasi Multimedia Interaktif Pada Pembelajaran Metode Tilawati Berbasis Web Responsive. JRST (Jurnal Riset Sains Dan Teknologi), 3(1), 1-7. https:/ / doi.org/10.30595/jrst.v3i1.3964

Aminudin, Basuki, S., \& Yusuf, M. (2019). Penerapan Perangkat Lunak Multimedia Interaktif Pembelajaran Al-Qur'an Dengan Metode Tilawati Cabang Malang. Jurnal Pengabdian Dan Pemberdayaan Masyarakat, 3(1), 173-178.

Fathoni, K., Utomo, A. B., Hangga, A., \& Pamungkas, O. P. (2018). Pengembangan Media Pembelajaran Al-Qur'an Berbasis Android di TPQ Al-Falah Semarang. Edu Komputika Journal, 5(2), 110-116. https:// doi.org/10.15294/EDUKOMPUTIKA.V5I2.27165

Hariani, L. S., \& Andayani, E. (2020). Diklat Keterampilan Pembelajaran Berbasis Multimedia untuk Meningkatkan Kompetensi Guru Taman Pendidikan Qur'an. JPM (Jurnal Pemberdayaan Masyarakat), 5(2), 522-529. https:// doi.org/10.21067/jpm.v5i2.4398

Hidayat, A. R., Hamdi, A. I., Damayati, I. A., Diva, N. A., \& Arifah, M. N. (2021). Perancangan Media Pembelajaran Interaktif Berbasis Aplikasi sebagai Pengembangan Kegiatan TPA di Masa Pandemi Covid-19. Jurnal Mahasiswa FIAIUII, at-Thullab, 3(1), 663-672.

Indra, H. (2020). Taman Pendidikan Al-Qur'an Berbasis Pendidikan Manusia. Risâlah, Jurnal Pendidikan Dan Studi Islam, 6(1), 150-164. https://doi.org/10.31943/jurnal_risalah.v6i1.134

Putra, H. W. S., Pranoto, R., Sari, A. N., Suryan, V., \& Herlinawati, H. (2021). Pengembangan Prasarana Masjid Untuk Taman Pendidikan Al-Qur'an (TPA) Di Masjid Jamiatul Ihsan Sukabangun. Darmabakti: Jurnal Inovasi Pengabdian Dalam Penerbangan, 1(2), 131-149. https:/ / doi.org/10.52989/ darmabakti.v1i2.26

Putra, L. D., \& Suyitno, S. (2018). Multimedia Pembelajaran TPA Berbasis Komputer 
Dengan Metode Qiro'ati. Jurnal Pemberdayaan: Publikasi Hasil Pengabdian Kepada Masyarakat, 1(2), 319. https:/ / doi.org/10.12928/jp.v1i2.301

Saefulloh, M. A. (2015). Upaya Optimalisasi Sarana dan Prasarana Sekolah dalam Meningkatkan Waktu Aktif Belajar Siswa: Penelitian Tindakan Kelas Pada Siswa Kelas V SDN Cigedug 03 Kabupaten Garut. Universitas Pendidikan Indonesia.

Saputra, A., \& Yuniansyah. (2018). Pengembangan Multimedia Untuk Meningkatkan

Kemampuan Mengenal Huruf Hijaiyah Pada Anak-Anak. Seminar Nasional

Teknologi Informasi Dan Komunikasi (SEMNASTIK) X, 76-82.

Setiawan, D., Rusdi, A., \& Putri, V. A. (2018). Peran TPA dalam Penyelenggaraan Pendidikan Al-Qur' an di Masjid Al-Fattah Palembang. JIP: Jurnal Ilmiah PGMI, 3(2), 170-184. https:// doi.org/10.19109/jip.v3i2.1650

Sri Bulan, \& W Eka Wahyudi. (2021). Pengembangan Media Pembelajaran Al-Qur'an Hadits Terintegrasi Seni Melalui Narasi Berbasis Gambar Bercerita Surat Al-Fil Untuk Membangun Kemampuan Berpikir Siswa. Journal of Instructional and Development Researches, 1(1), 10-19. https://doi.org/10.53621/jider.v1i1.18.

\footnotetext{
* Mochammad Taufik, S.T., M.T (Corresponding Author) Politeknik Negeri Malang

Jl. Sukarno Hatta No. 9 Malang, East Java, 65141, Indonesia

Email: moch.taufik@polinema.ac.id

Ir. Hudiono, M.T.

Politeknik Negeri Malang

Jl. Sukarno Hatta No. 9 Malang, East Java, 65141, Indonesia

Email: hudiono@polinema.ac.id
}

Aad Hariyadi, S.ST., M.T.

Politeknik Negeri Malang

Jl. Sukarno Hatta No. 9 Malang, East Java, 65141, Indonesia

Email: aad.hariyadi@polinema.ac.id

Ridho Hendra Yoga Perdana, S.ST., M.T.

Politeknik Negeri Malang

Jl. Sukarno Hatta No. 9 Malang, East Java, 65141, Indonesia

Email: ridho.hendra@polinema.ac.id

Amalia Eka Rakhmania, S.T., M.T., M.Sc.

Politeknik Negeri Malang

Jl. Sukarno Hatta No. 9 Malang, East Java, 65141, Indonesia

Email: amaliaeka.rakhmania@polinema.ac.id 